\title{
Lithuanian Language
}

National Cancer Institute

\section{Source}

National Cancer Institute. Lithuanian Language. NCI Thesaurus. Code C154003.

An Indo-European Baltic language that is the official language of Lithuania. 